\title{
TCL1A wt Allele
}

National Cancer Institute

\section{Source}

National Cancer Institute. TCL1A wt Allele. NCI Thesaurus. Code C92700.

Human TCL1A wild-type allele is located in the vicinity of 14q32.1 and is approximately 4 $\mathrm{kb}$ in length. This allele, which encodes $\mathrm{T}$-cell leukemia/lymphoma protein $1 \mathrm{~A}$, plays a role in the modulation of signal transduction. Chromosomal aberrations involving the gene are associated with chronic $T$-cell leukemia, including translocation $t(14 ; 14)(q 11 ; q 32)$ which involves the T-cell receptor beta locus; and translocation t(7;14)(q35;q32) and inversion inv(14)(q11;q32) which both involve the T-cell receptor alpha/delta loci. 